КРИТЕРІЇ ПОРІВНЯЛЬНОЇ ХАРАКТЕРИСТИКИ ПРОФЕСІЙНОЇ ПІДГОТОВКИ МАЙБУТНІХ ФАХІВЦІВ ТЕАТРАЛЬНОГО МИСТЕЦТВА В УКРАЇНІ ТА США

\title{
CRITERIA OF COMPARATIVE CHARACTERISTICS OF FUTURE THEATER ART SPECIALISTS' PROFESSIONAL TRAINING IN UKRAINE AND THE USA
}

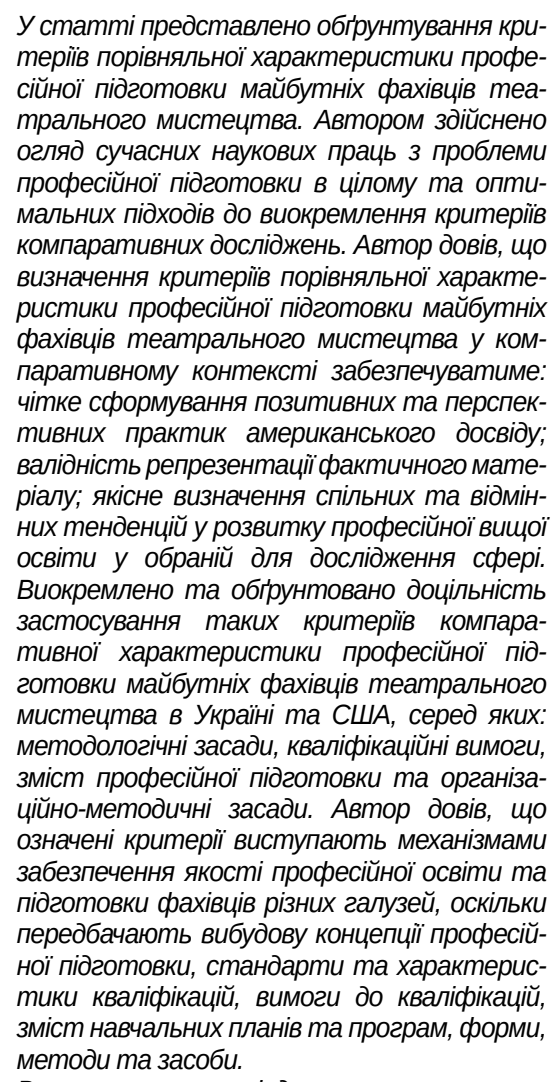

Встановлено, що індикаторами та компонентами порівняльної характеристики в методологічних засадах виступатимуть концепція профресійної підготовки майбутніх фрахівців театрально мистецтва, підходи та принципи); у квалісрікаційних вимогах це квалірікації, особливості здобуття профресійної освіти - терміни та інституиі де можна здобути професію; у змістовому блоці - це навчальні плани, програми професійної підготовки майбутніх фрахівців театрально мистецтва, в яких викладена мета, завдання та компетентності; в організаційно-методичних засадах - форми, методи та засоби.

Ключові слова: профресійна підготовка, фрахівці театрального мистецтва, крите- рії компаративної характеристики, компоненти системи.

The criteria of comparative characteristics of future specialists in theatrical art professional training are presented in the article. The author reviews modern scientific works on the problem of professional training in general and optimal approaches to the selection of criteria for comparative research. The author distinguished, that the definition of criteria for the comparative characterization of future theater professionals professional training in a comparative context will provide: a clear formation of positive and promising practices of the American experience; validity of representation of factual material; qualitative definition of common and different trends in the development of professional higher education in the field chosen for research.

The author proved and explained the application of such criteria of comparative characteristic of future specialists of theatrical art professional training in Ukraine and the USA, these criteria are distinguished and explained from the practical point of usage. These criterias are: methodological principles, qualification requirements, content of professional training and organizational-methodical principles. The author proved, that these criteria are mechanisms for ensuring the quality of vocational education and training of specialists in various fields, as they provide a concept of training, standards and characteristics of qualifications, qualification requirements, content of curricula, forms, methods and tools.

It is established that the indicators and components of comparative characteristics in methodological principles will be the concept of professional training of future specialists in theatrical art, approaches and principles); in qualification requirements - these are qualifications, features of vocational education - terms and institutions where you can get a profession; in the substantive block - these are curricula, training programs for future specialists in theatrical art, which set out the purpose, objectives and competencies; in organizational and methodological principles forms, methods and means.

Key words: professional training, specialists of theatrical art, criteria of comparative characteristic, system components. університету (США)

Постановка проблеми в загальному вигляді. Компаративні дослідження в сорері професійної освіти, як у вітчизняній теорії і практиці, так і зарубіжній набувають все більшої актуальності в контекстах наукових дискусій щодо глобалізації освітніх просторів окремих країн та міжнародної освіти в цілому. У галузі освітньої політики та концепції подальшого розвитку вищої профресійної освіти Європейським Союзом, наприклад, було ініційовано програму Леонардо да Вінчі, що забезпечила основний поштовх для актуалізації порівняльних досліджень у профресійній освіті (VET) [31, с. 12].
Актуальності набувають дослідження у різних галузях: педагогіки, психології лінгвістики, мистецтва. Сорера інтересів останнього лежить у площині міжкультурної та між особистісної комунікації на регіональному, національному та міжнародних рівнях, що визначає і особливий статус професійної підготовки майбутніх фрахівців театрального мистецтва.

Аналіз останніх досліджень і публікацій. У тематиці компаративних досліджень визначення ролі акторського мистецтва для загальнолюдської культури та фрормування гуманістичних і демократичних цінностей [25; 26; 37]; не залишаються 
поза увагою компаративістів традиційні та сучасні техніки театрального мистецтва [46; 45; 41], підходи [22; 30] тощо.

Варто також зазначити, що здійснення компаративних досліджень у будь-якій галузі, зокрема у професійній підготовці майбутніх фрахівців театрального мистецтва вимагає обґрунтування критеріїв за якими здійснюватиметься порівняльний аналіз, метою якого зазвичай є встановлення позитивних та перспективних здобутків певної обраних для дослідження систем сорери професійної освіти. Необхідність виокремлення таких критеріїв визначається насамперед тим, що завдяки конкретним індикаторам у дослідника $€$ можливість критично інтерпретувати отримані фрактичні дані та результати, що підлягають ретельному аналізі кількісних та / або якісних, а також і статистичних даних. Відтак, не можна не погодитись 3 твердженням М. Красовицького, який вважав, що для компаративного дослідження важливою умовою здійснення якісного компаративного дослідження $€$ розроблення ключових параметрів порівняння відповідно до мети. Дослідник зазначав, що безсистемне збирання та опис фрактів дослідником без мети й чіткого визначення параметрів порівняльного аналізу не $є$ наукою, а лише описом, спогадами [7]. На переконання вченого визначення ключових параметрів порівняння дає можливість одержати чіткі відповіді на ті питання, які цікавлять дослідників або керівників української освіти [6, с. 46].

Тож у дослідженні проблеми професійної підготовки майбутніх фахівців театрального мистецтва у компаративному контексті визначення критеріїв порівняльної характеристики, що дозволить: чітко сорормувати позитивні та перспективні практики американського досвіду; забезпечить валідність репрезентації фрактичного матеріалу; визначити спільні та відмінні тенденції (аспекти системи професійної підготовки, компоненти чи складники тощо) у розвитку профресійної вищої освіти у обраній для дослідження сорері. 3 огляду на актуальність зазначеного, метою cmammi є обґрунтування критеріїв порівняльної характеристики профресійної підготовки майбутніх фрахівців театрального мистецтва в Україні та США.

Сорормулювала мета реалізовуватиметься в процесі розв'язання таких завдань: по-перше - виокремлення критеріїв порівняльного аналізу, їхня характеристика; по-друге - обґрунтування необхідності застосування визначених критеріїв; по-третє - конкретизація критеріїв порівняльної характеристики професійної підготовки майбутніх фрахівців театрального мистецтва для започаткованого дослідження.

Методологія та методи. Розв'язання поставленої мети також можливе за умови застосування аналітичного, прагматичного, наративного та компаративного підходів у процесі здійснення дослі- дження, пов'язаного з визначенням вітчизняної та зарубіжної термінології, запропонованого (Мельник, 2017). Оскільки запропоноване дослідження передбачає визначення основних понять із врахуванням зарубіжної термінології, то доцільним вважаємо застосування таких методів, як аналіз та вивчення понять у довідковій літературі та наукових працях, компаративний зіставний аналіз, синтез та узагальнення аналітично отриманих понять.

Виклад основного матеріалу. Здійснення порівняльної характеристики професійної підготовки майбутніх фрахівців театрального мистецтва в Україні та США вважаємо за доцільне розпочинати 3 аналізу методологічної концепції професійної освіти. Обґрунтовуючи свою позицію в цьому аспекті, звернімося до дослідження Ю. Латербаха та В. Міттера, яке засвідчило, що ігнорування методологічних засад профресійної підготовки у порівняльних дослідженнях часто призводить до не можливості об'єктивності інтерпретації певних методичних підходів, технік та об'єктів педагогічного компаративного дослідження. На думку авторів, методологічні концепції, що часто не обґрунтовуються в порівняльних дослідженнях у сорері професійної підготовки, у багатьох випадках $€$ суто випадковими, але, як засвідчила практика для багатьох дослідників методологічні питання мали граничне значення, оскільки результати таких досліджень не були позбавлені суперечок через відсутність методологічної основи. Критична оцінка результатів дослідження, в якій методологічна концепція та основний інтерес порівняння не були розкриті характеризувалась слабкою валідністю та піддавалась сумніву [31, с. 12]. Саме тому, на наше переконання, важливо розпочинати порівняльну характеристику двох систем професійної підготовки, а в нашому випадку - української та американської - з огляду методологічних засад.

Звертаючись до визначення самого френомену «методологічні засади» зазначимо, що розуміємо у контексті таких його тлумачень: 1) за визначенням, запропонованим В. Краєвським: «...методологія в широкому розумінні трактують як «систему принципів і способів побудові теоретичної і практичної діяльності, а також вчення про цю систему» [6, с. 11], а «засади» в започаткованому дослідженні-це, за Академічним тлумачним словником, «основа чогось; те головне, на чому ґрунтується, базується що-небудь; вихідне, головне положення, принцип; основа світогляду, правило поведінки; спосіб, метод здійснення чого-небудь» [19]. Варто також підкреслити, що існує принципова різниця між методологією наукового дослідження та методологією здійснення професійної підготовки. Так, методологія наукового дослідження - це система методологічних і методичних принципів і прийомів, операцій і фрорм побудови наукового знання; це концептуальний виклад мети, змісту, методів 
дослідження, які забезпечують отримання максимально об'єктивної, точної, систематизованої інорормації про процеси та явища [10, с. 72]. Тоді як методологія профресійної підготовки фрахівців певної галузі визначається фрілософськими засадами та концепціями, фрормулюванням загальних принципів і методів реалізації освітнього процесу в цілому та побудову педагогічних теорій щодо вдосконалення цього процесу тощо [9, с. 29].

Отже, методологія здійснення професійної підготовки майбутніх фрахівців - це комплекс підходів та принципів до здійснення певного освітнього процесу, що можуть детермінуватися як внутрішніми (оптимізація здійснення освітнього процесу, особливостями учасників освітнього процесу тощо), так і зовнішніми (освітня політика, наукові дослідження тощо) чинниками. На основі зазначеного до методологічних засад профресійної підготовки фрахівців театрального мистецтва відносимо: загальну концепцію професійної підготовки фрахівців театрального мистецтва, що представлена через українські (Закон України «Про театри і театральну справу» [3]), Концепції реалізації державної політики у сфрері профресійної (професійно-технічної) освіти «Сучасна профресійна (професійно-технічна) освіта» на період до 2027 року, затвердженої розпорядженням Кабінету Міністрів України від 12 червня 2019 р. № 419-р [5], Стратегію розвитку профресійної (профресійно-технічної) освіти на період до 2023 року [12] та американські (положення та рекомендації Національної Ради 3 питань мистецтва [33], Національного фронду мистецтв [44], висновки та інструкції Національного фронду Управління 3 питань цивільних прав та рівних можливостей працевлаштування фрахівців мистецтв [44], концептуальні документи Національного інституту драматичного мистецтва [35; 36; 34], державні нормативні документи та наукові концепції, що висвітлені у наукових дослідженнях провідних та незалежних організацій та асоціацій, фрахівців галузі, вчених та практиків тощо, що визначає основні підходи та принципи здійснення професійної підготовки фрахівців театрального мистецтва.

Наступним критерієм порівняльної характеристики виступатиме опис системи професійної підготовки. Аналіз компаративних досліджень вітчизняних дослідників (О. Дубасенюк [14], Н. Мельник, В. Вертугіна, Л. Артемова, О. Авраменко, Н. Павлушенко [32], Л. Пуховської [16] та інших) та зарубіжних вчених (Р. Інджерсол [28], Е. Герш, Дж. Копич, М. Кнап [28], Р. Пряйер [38], К. Роджерса, К. Скотта [39] тощо) засвідчує, що опис систем профресійної освіти та їхня порівняльна характеристика уможливлює на основі об'єктивного співставлення певних структурних елементів систем та виокремлення на цій основі перспективних аспектів фрунк- ціонування певної системи профресійної підготовки, визначення переваг та недоліків у контексті інституційних компонентів.

У розумінні поняття «система професійної освіти» вкладаємо фрормулювання запропоноване у Законі України «Про професійну (профресійнотехнічну) освіту», в якому система профресійної (профресійно-технічної) освіти це мережа закладів профресійної (профресійно-технічної) освіти незалежно від фрорм власності та підпорядкування, що проводять діяльність у галузі профресійної (професійно-технічної) освіти, навчально-методичних, науково-методичних, наукових, навчально-виробничих, навчально-комерційних, видавничо-поліграсрічних, культурно-освітніх, фрізкультурно-оздоровчих, обчислювальних та інших підприємств, установ, організацій та органів управління ними, що здійснюють або забезпечують підготовку кваліфрікованих робітників [11]; а також це - комплексом педагогічних та організаційно-управлінських заходів, спрямованих на забезпечення оволодіння громадянами знаннями, уміннями і навичками в обраній ними галузі профресійної діяльності, розвиток компетентності та професіоналізму, виховання загальної і професійної культури. Професійна (професійно-технічна) освіта здобувається у закладах [13]. На переконання Н. Ничкало, система професійної освіти виконує різні фрункції, до яких належать соціальна, економічна, культуро творча, освітня, пізнавальна, що тісно взаємопов'язані й реалізуються в системній взаємодії навчальних закладів різних типів і фрорм власності, підприємств та організацій усіх економічних секторів, соціальних партнерів, громадських організацій, об'єднаних територіальних громад, органів державної влади та управління [17, с. 72].

Одним із механізмів забезпечення ефективного фрункціонування системи професійної підготовки $€$ стандарти вищої професійної освіти [20, с. 12-13], які в Україні є трьохкомпонентними: освітньо-кваліфрікаційна характеристика (ОKX), освітньо-профресійна програма (ОПП) та засоби діагностики якості вищої освіти. Складниками якості - OKX та ОПП - визначено вимоги професійної підготовки, а також з боку держави, світового співтовариства та споживачів до змісту освітньої системи закладу вищої освіти (3ВО) [18, с. 172]. Наголосимо також, що одним із допоміжних механізмів у інструментарії Європейської базової рамки забезпечення якості освіти відповідно до списку з 10 показників (відомих як показники EQARF (European Quality Assurance Reference Framework - Європейська базова рамка забезпечення якості) та за допомогою якого можна перевірити якість та ефрективність системи професійної освіти і навчання є програми профресійної підготовки (ОКХ та ОПП) [40]. У списку три показники безпосередньо стосуються програм професійної освіти, а саме: рівень участі 
у програмах професійної освіти, рівень завершення програм профресійної освіти, рівень розміщення на програмах професійної освіти [40].

щодо першого компонента зазначимо, що відповідно до дослідження Р. Інджерсола одним із найважливішим критерієм за практикою компаративних досліджень $€$ дослідження та зіставлення кваліфікаційних вимог до майбутнього фрахівця [29]. Кваліфрікаційні вимоги (КВ), за твердженням Н. Мельник, виступають регуляторами ефективного функціонування всієї системи професійної підготовки та якості педагогічної освіти у дошкільній галузі, що становить подальший зміст дисертаційної роботи [8, с. 246]. Окрім того, як свідчить аналіз Н. Мельник, це - одна із ключових у забезпеченні якості педагогічної освіти, спосіб, через який трансформується загальноєвропейська концепція орормування професійних компетентностей та засіб кореляції національних професійних стандартів з Європейською кваліфрікаційною Рамкою [8, с. 246-250].

Відповідно до визначення запропонованого Європейським центром розвитку професійного навчання (Cedefop), цей термін зазвичай використовується у двох значеннях:

(a) офріційна кваліфікація: офріційний результат (сертиорікат, диплом або звання) процесу оцінювання та підтвердження, який отримується, коли компетентний орган визначає, що особа досягла знань результати за заданими стандартами та / або володіє необхідною компетенцією для виконання роботи в певній галузі роботи; кваліфікація надає офріційне визнання значення результатів навчання на ринку праці та в освіті та навчанні, і може бути законним правом займатися професією;

(б) вимоги до роботи: знання, здібності та навички, необхідні для виконання конкретних завдань, прикріплених до певної робочої посади [24, с. 37].

Механізми забезпечення якості профресійної освіти та підготовки фрахівців різних галузей передбачають вимоги до кваліфікацій, що можуть формуватися через стандарти та характеристики кваліфрікацій, через оцінку якості професійної діяльності та рівнем акредитації закладів вищої освіти [25, с. 40]. Емпіричне дослідження Європейського центру розвитку професійного навчання (Cedefop) демонструє, що в деяких країнах офріційні механізми забезпечення якості фрункціонують на рівні системи професійної освіти в цілому або на рівні інституцій, що забезпечують надання освітніх послуг, які передбачають процес сертифрікації, тобто видання дипломів, сертифрікатів та інших документів, що засвідчують рівень професійної підготовки випускника чи слухача, який відвідував ці інституції. Це залежить від способу організації системи професійної освіти та системи присвоєння кваліфрікації, наприклад, чи проходять сертифрікаційні іспити в закладах професійної освіти чи це здача іспитів у незалежних екзаменаційних центрах, а також від того, наскільки система забезпечення якості покладається на зовнішнє оцінювання та самооцінку [25, с. 40-41].

У контексті нашого дослідження будуть підставлятися кваліфікаційні вимоги до компетентності та особливості кваліфрікацій, що надаються випускникам після закінчення професійної підготовки майбутніх фрахівців театрального мистецтва в Україні та США; порівнюватимуться також документи, що видають університети чи інші заклади освіти, які функціонують у системи професійної підготовки фахівців театрального мистецтва в Україні та США. Отже, одним із критеріїв професійної підготовки майбутніх фрахівців театрального мистецтва в Україні та США будуть кваліфікаційні вимоги, які представлені через: законодавчі та нормативні документи (Довідник кваліфрікаційних характеристик професій працівників [2].

Ще одним із важливих засобів забезпечення якості професійної освіти та підготовки фрахівців, за результатами дослідження Європейського центру розвитку професійного навчання, вважаються програми, що спрямовані на прицільну профресійну підготовку фахівців у кожній окремій галузі. Програми визначають зміст професійної освіти, який виступає індикатором якості професійної підготовки фрахівців будь-якої галузі [25, с. 40]. Зміст навчання, за визначенням Європейського центру розвитку професійного навчання, - це теми та види діяльності, з яких складається освітня програма, що вивчає особа або група студентів (майбутніх фрахівців), які здобувають певну фрорму освіти в освітньому закладі у контексті цілеспрямованого організованого навчального процесу [42, с. 166]. Відповідно до Глосарію термінології навчального плану, зміст освіти - це теми, теми, переконання, поведінка, концепції та фракти, часто згруповані в межах кожного предмета чи навчального матеріалу область під знаннями, навичками, цінностями та установками, що очікується, що вони будуть вивчені і становлять основу викладання та навчання [27, с. 36]. Зміст профресійної підготовки фрахівців в українському науковому просторі - це поглиблене ознайомлення 3 науковими основами й технологією обраного виду праці; прищеплення практичних навичок та вмінь; фрормування психологічних та соціальних якостей особистості, необхідних для роботи у певній сфері людської діяльності [21, с. 275]; це також - сукупність відомостей необхідних для виконання в майбутньому конкретної профресійної діяльності, у скороченій фрормі зміст професійної освіти представлено у навчальних планах і програмах, а розгорнуто - у підручниках, навчальних посібниках, лекціях та розробках практичних і семінарських занять викладачів [14, с. 308-309]. Отже, зміст професійної підготовки забезпечує профресійну компетентність майбутнього фрахівця, а його якість - готовність та 
конкурентноспроможність на ринку праці. Зазначимо, що зміст профресійної підготовки майбутніх фахівців театрального мистецтва в Україні та США репрезентовано у навчальних планах, освітніх програмах підготовки (ОПП), навчальних та робочих програмах, силабусах освітніх програм тощо, що укладаються закладами вищої освіти на основі рекомендацій запропонованих державними інституціями, або ж незалежними асоціаціями фрахівців означеної галузі. Отже, компаративному аналізу підлягатимуть навчальні плани, курикулуми, освітні програми та робочі програми дисциплін (в тому числі силабуси) професійної підготовки майбутніх фрахівців театрального мистецтва в Україні та США.

Логіка здійснення компаративного дослідження вимагає також розгляд об'єктів педагогічного явища і на локальному рівні, а саме аналіз та порівняння організаційно-методичних умов здійснення професійної підготовки фахівців певної галузі у зміст якого вкладаємо розуміння понять: 1) організаційна фрорма навчання - зовнішній вигляд організації навчального процесу [21, с. 240]; 2) методичне забезпечення (від понять метод навчання - багатоякісне педагогічне явище, яке передбачає гносеологічний, логіко-змістовий, психологічний та матеріально-джерельний аспекти взаємопов'язаної діяльності педагога та вихованців спрямованих на розв'язання навчально-виховних завдань та освітньої мети [21, с. 206]; спосіб досягнення певної цілі, сукупність прийомів та дій практичного та теоретичного засвоєння дійсності [15, с. 163]; комплекс дій спрямованих на організацію освітньо-пізнавальної діяльності [4, с. 181]; 3) забезпечення - сукупність норм, інструкцій, положень, матеріальних та технічних засобів, що описують технологію виконання певного процесу та технологію фрункціонування системи, методи вибору та застосування користувачами технологічних прийомів чи матеріальних об'єктів, що приведуть до отримання позитивного результату [1, с. 375].

Зазначимо, що вивчення та компаративний аналіз організаційно-методичних умов профресійної підготовки майбутніх фрахівців театрального мистецтва в Україні та США уможливить співставлення та порівняння таких компонентів системи професійної освіти як форми організації навчання, методи та засоби реалізації освітнього процесу, що виступатимуть складниками означеного критерію.

Висновки. Здійснений аналіз, систематизація характеристика та обґрунтування доцільності застосування різних критеріїв порівняльної характеристики в процесі здійснення компаративних досліджень в цілому уможливлює виокремлення критеріїв порівняльної характеристики професійної підготовки майбутніх фрахівців театрального мистецтва в Україні та США, до яких відносимо: методологічні засади (концепція професійної підготовки майбутніх фрахівців театрально мистецтва, підходи та принципи); кваліфікаційні вимоги (кваліфікації, особливості здобуття профресійної освіти - терміни та інституції де можна здобути професію), що в свою чергу визначають зміст, що викладений у програмах профресійної підготовки майбутніх фрахівців театрально мистецтва (мета, завдання, компетентності, які набуватимуть майбутні фрахівці театрального мистецтва в процесі здобуття професійної освіти, техніки, якими мають володіти майбутні фрахівці), а також організаційно-методичні засади (форми, методи та засоби). Водночас, варто підкреслити, що критерії порівняльної характеристики це лише перший етап до цілісного представлення компаративного дослідження професійної підготовки майбутніх фрахівців театрально мистецтва, деталізації та конкретизації потребує саме співставлення досліджуваних педагогічних явищ, що становить перспективи представлення результатів започаткованого дослідження у наших подальших наукових публікаціях та роботі.

\section{БІБЛІОГРАФІЧНИЙ СПИСОК:}

1. Великий тлумачний словник сучасної української мови / уклад. Бусел В.Т. Київ ; Ірпінь : Перун, 2005. 1728 c.

2. Довідник квалісрікаційних характеристик профресій працівників. Вип. 1: Професії працівників, що $€$ загальними для всіх видів економічної діяльності Головбух 24. URL: http://zakon.golovbukh.ua/regulati ons/1521/8453/8454/468492.

3. Закон України «Про театри і театральну справу». URL: https://zakon.rada.gov.ua/laws/show/ 2605-15\#Text.

4. Коджаспирова Г.М., Коджаспиров А.Ю. Словарь по педагогике. Москва : ИКЦ «МарТ» ; Ростовна-Дону : Издат. центр «МарТ», 2005. 448 с.

5. Концепції реалізації державної політики у сорері професійної (професійно-технічної) освіти «Сучасна професійна». URL: https://zakon.rada.gov. ua/laws/show/419-2019-\%D1\%80\#Text.

6. Краевский В.В., Бережнова Е.В. Методология педагогики: новый этап : учеб пособ. Москва, 2006. С. 11.400 c.

7. Краевский В.В. Проблемы научного обоснования обучения (Методологический анализ). Москва : Педагогика, 1977. 264 с.

8. Мельник Н.І. (2017). Теоретичні і методичні засади професійної підготовки дошкільних педагогів у країнах Західної Європи : дис. ... д-ра пед. наук : 13.00.04 «Теорія і методика професійної освіти»; 13.00.08 «Дошкільна педагогіка». Уманськ. держ. пед. ун-т ім. Павла Тичини. Умань. URL: https://core.ac.uk/download/pdf/127440586.pdf.

9. Внукова О.М. Методологічні засади професійної освіти : навчальний посібник для студентів напрямів підготовки 6.010104 Профресійна освіта (Технологія виробів легкої промисловості), 6.010104 Профресійна освіта (Дизайн). Київ : КНУТД, 2015. 198 c. 
10. Методологія наукових досліджень : навч. посіб. / В.І. Зацерковний, І.В. Тішаєв, В.К. Демидов. Ніжин : НДУ ім. М. Гоголя, 2017. 236 с.

11. Про профресійну (професійно-технічну) освіту : Закон України. URL: https://zakon.rada.gov.ua/laws/ show/103/98-\%D0\%B2\%D1\%80\#Text.

12. Проєкт Стратегія розвитку профресійної профресійної (професійно-технічної) освіти на період до 2023року. URL:https://mon.gov.ua/app/media/2020/11/04

13. Професійна освіта. Інститут модернізації змісту освіти. URL: https://imzo.gov.ua/osvita/ profesiyno-tehnichna-osvita-2/profesiyna-osvita.

14. Профресійна педагогічна освіта: компетентнісний підхід : монограсрія / кол. авт.: О.А. Дубасенюк (ред.), О.Є. Антонова [та ін.] ; за ред. О.А. Дубасенюк] ; Житомир. держ. ун-т ім. Івана Франка. Житомир : Вид-во ЖДУ ім. І. Франка, 2011. 411 с.

15.Профессиональное образование: Словарь. Ключевые понятия, термины, актуальная лексика Москва : МНЦ СПО, 1999. 538 с.

16. Пуховська Л. П. Професіоналізм учителя в різних освітніх системах: порівняльний аналіз. Вісник Житомирського державного педагогічного університету / Житомир. держ. пед. ун-т ім. І. Франка. Житомир 2000. Вип. 6. С. 3-5.

17. Ничкало Н.Г. Розвиток профресійної освіти в умовах глобалізаційних та інтеграційних процесів : монографрія. Київ : Видавництво НПУ імені М.П. Драгоманова, 2014. 125 с.

18. Сікора Я. Особливості змісту професійної підготовки бакалаврів інформатики. Наукові записки. Серія: Проблеми методики фрізико-математичної і технологічної освіти. Вип. 7 (I). С. 170-174.

19. Словник української мови : в 11 т. Київ : Наукова думка, 1970-1980. URL: http://sum.in.ua/s/zasada.

20. Стандарти і рекомендації щодо забезпечення якості в Європейському просторі вищої освіти. Київ : Ленвіт, 2006. 35 с.

21. Український педагогічний словник. (Довідкове видання) С. Гончаренко. Київ : Либідь, 1997. 375 с.

22. Acting in the Academy: The history of professional actor training in US higher education. Peter Zazzali. London, New York : Routledge, 2016.

23. Cedefop (2015). Ensuring the quality of certification in vocational education and training. Luxembourg : Publications Office. Cedefop research paper; No 51. URL: http://dx.doi.org/10.2801/25991

24. CEDEFOP (European Centre for the Development of Vocational Training). 2011. Glossary. Quality in education and training. Luxembourg : Publications Office of the European Union.

25. Donnellan, Declan. The Actor and the Target. St. Paul, MN:Theatre Communications Group, 2002.Print.

26. Esper, William, and Damon DiMarco. The Actor's Art and Craft: William Esper Teaches Meisner Technique. New York : Anchor, 2008. Print.

27. Glossary of Curriculum Terminology. UNESCO International Bureau of Education. Published in September 2013 by the UNESCO International Bureau of Education (UNESCO-IBE).

28. Hirsch, E., Koppich, J., \& Knapp, M. (2001). Revisiting what states are doing to improve the quality of teaching: An update on patterns and trends. Center for the Study of Teaching and Policy, University of Washington.
29. Ingersoll, R. (2007). A Comparative Study of Teacher Preparation and Qualifications in Six Nations. CPRE Policy Briefs. RB-47.

30. Kathleen Gallagher, Lindsay Valve \& Christine Balt (2021) Building new publics: using agile, community-engaged, and applied theatre methodologies as social intervention in audience research, Research in Drama Education: The Journal of Applied Theatre and Performance, 26:2, pp. 318-334, DOI: 10.1080/13569783.2021.1876557.

31. Lauterbach U., Mitter V. Theory and methodology of international comparisons. Vocational education and training - the European research field Background report - Volume II. Luxembourg : Office for Official Publications of the European Communities, 1998. ISBN 92-828-3614-2.

32. Nataliia I. Melnyk, Valentyna M. Vertuhina, Liubov V. Artemova, Oksana O. Avramenko, Nataliia M. Pavlushchenko (2020). Progressive Practices of Government management in Preschool Teachers Professional Training in Western European Countries. Universal Journal of Educational Research, 8(10), pp. 4591-4602. DOI: 10.13189/ujer.2020.081027. http://www.hrpub.org/ journals/article_info.php?aid=9806.

33. National Council on the Arts. Task Force on Hispanic American Arts URL: https://www.arts.gov/about/ leadership-staff/national-council-arts.

34. National Institute of Dramatic Art. (2014c). NIDA fair treatment and equal opportunity policy. URL: https://www.nida.edu.au/_data/assets/pdf_file/ 0020/14294/Fairtreatment-and-equal-opportunity-policy.pdf.

35. National Institute of Dramatic Art. (2015a). NIDA student policies and procedures. URL: https://www.nida. edu.au/courses/graduate/nida-student-policies.

36. National Institute of Dramatic Art. (2015b). Undergraduate acting. URL: https://www.nida.edu.au/courses/ undergraduate/acting.

37. Prabhath B. A comparative study of the contemporary actors training process in $\mathrm{NOH}$ and Kutiyattam. 2011. Department of Theatre Arts. University of Hyderabad.

38. Prior, Ross W. Characterising Actor Trainers' Understanding of their Practice in Australian and English Drama Schools. 2005. Thesis (PhD Doctorate). School of Vocational, Technology and Arts Education. URL: https://research-repository.griffith.edu.au.

39. Rodgers, C., \& Scott, K. (2008). The development of the personal self and professional identity in learning to teach. In M. Cochran-Smith, S. Feiman-Nemser, D.J. McIntyre \& K.E. Demers (Eds.), Handbook of research on teacher education: Enduring questions and changing contexts (pp. 732-755). New York: Routledge.

40.Seyfried, Erwin: "Accreditation and quality assurance in VET - selected European approaches", CEDEFOP 2009

41. Stanislavsky, Konstantin. An Actor Prepares. New York : Routledge, 2003. Print.

42. Terminology of European education and training policy. A selection of 100 key terms. Luxembourg: Office for Official Publications of the European Communities, 2008.

43. The National Endowment for the Arts' Office of Civil Rights and Equal Employment Opportunity (OCREEO). URL: https://www.arts.gov/about/civil-rights-office. 
44. The National Endowment for the Arts. URL: https://www.arts.gov.

45. Vakhtangov, Evgeniī, and Andrei Malaev-Babel. The Vakhtangov Sourcebook. London : Routledge, 2011. Print.
46. Zubrzycki, Anna (2014) "Actor Training and Techniques in Pieśn Kozła Theatre", Mime Journal: Vol. 25, Article 6. DOI: 10.5642/mimejournal.20142501.06 URL: http://scholarship.claremont.edu/mimejournal/vol25/ iss $1 / 6$. 